\title{
Intersectional Inheritances in Can You Hear the Nightbird Call?
}

\author{
Priya Uthaiah .I \\ Assistant Professor of English \\ Government College, Mandya \\ Dr.Devika Rani.L \\ Associate Professor of English \\ Dept. of Studies \&Research in English \\ University of Mysore
}

\begin{abstract}
The term inheritance bespeaks of intergenerational bequeathing of a legacy. Legacies inherited by descendants of an earlier generation could be pecuniary, political or patriarchal. Of the three aforementioned legacies the first two-pecuniary and political are vulnerable to the buffets of fortune while a patriarchal legacy from generations past, permeates to the present generation and subsequently to the future, perpetuating itself with its numerous intersections and thus retaining its robustness as a living legacy. As a result the intersections in patriarchy get handed down as a continuum across generations from predecessors to successors. This paper is an attempt to delineate a few intersectional inheritances within the Indian social milieu vis-à-vis the theory of intersectionality, in Anita Rau Badami's novel Can You Hear the Nightbird Call?
\end{abstract}

Keywords: Intersectionality, inheritance, patriarchal legacy, stereotypes.

\section{INTRODUCTION}

In her narrative, in Can You Hear the Nightbird Call? Anita Rau Badami recreates events from the pages of Indian history bloodied by- the communal carnage during the country's Partition and the secessionist violence in Punjab. She chronicles the Indian state's armed retaliation to quell terrorism by storming the holiest shrine of Sikhs-The Golden Temple. This blasphemous intrusion by the Indian government is avenged by the assassination of Prime Minister Indira Gandhi, triggering the gruesome anti- Sikh riots. The fallout of this religious antagonism is the bombing of the Air India flight, in transit to India from Toronto on June 23,1985, claiming the lives of all 329 people on board . Against this backdrop, caught in the inexorable web of violence and vengeance are women belonging to three generations, whose lives have been afflicted by intersections in a patriarchal society like class, religion, gender, age, skin tone,etc. These factors through the process of socialisation, engender discrimination and gets perpetuated transgenerationally.

The story begins with the author narrating the childhood of Bibi-ji, an affluent Indian immigrant in Canada. Bibi-ji as a six year old child was called Sharanjeet Kaur who lived with her mother Gurpreet Kaur, father Harjot Singh and elder sister Kanwar Kaur in the village of Panjaur in Punjab, before India's Partition. In her marital home Gurpreet Kaur's life is one of domestic drudgery burdened by endless chores, in addition to raising crops in her meagre plot of land dependent on rains, to feed her family. Her husband Harjot Singh despondent over his futile voyage aboard the Komagata Maru lies on the cot all day, leading a life of indolence, relinquishing all his responsibilities towards his wife and daughters. Hence Gurpreet Kaur as the breadwinner of the family, as a wife and a mother is positioned at the crossroads where multiple aspects of her identity- gender, class, religion, interact with each other to create an arena of oppression. The interplay of these assigned roles at different levels resulting in multiple oppression can be understood and analysed through the theory of intersectionality.

The concept of "intersectionality" in feminist thought was introduced by legal scholar Kimberle Williams Crenshaw to draw attention to the intersectional space that Black women found themselves in, on account of their racial and sexual identities. Drawing an analogy to a traffic intersection, Crenshaw argues that issues of race and sex are not mutually exclusive. They interact with each other 
like different paths in an intersection. Thus intersectionality underlines the multiplicity of oppression against women whose identity, in addition to gender, is constructed by multiple factors like race, class, ethnicity, religion, nationality,etc. Cultural Historian Nancy Jouwe's explication of intersectionality is relevant to the analysis of intersectional inheritances in the lineage of female characters in Can You Hear the Nightbird Call?

Intersectionality refers to categories of difference that we embody simultaneously

(race, class, gender, sexuality, level of abledness and so on) and how these catego-

-ries interact with each other on an individual, institutional and symbolic level.

The outcomes of these interactions create different power positions, which means

we all inhabit different levels of privilege and discrimination. As such intersecti-

-onality can be useful to explain the specific forms of discrimination that Black

queer women face.....(1).

Thus we see that different identities that Gurpreet Kaur embodies as a woman (gender),as a female belonging to the lower economic strata of society (class), as a Sikh(religion)- which gives Gurpreet her last name "Kaur" meaning princess, an ironic suffix considering her situation in a patriarchal society- interact with simultaneity at different levels. At an individual level Gurpreet is a female who undoubtedly would have wished for a comfortable life, but the domestic and economic roles assigned to her as a wife, a mother and as a breadwinner compel her to conform to gender stereotypes, personifying feminine virtues like subservience and sacrifice. The simultaneous interactions of Gurpreet's identity at the individual, institutional and symbolic levels "create different power positions" making her "inhabit different levels of privilege and discrimination" (Jouwe 1).

As an individual earning a livelihood, providing for and taking care of her idle husband and two daughters, one could argue that ideally Gurpreet should have occupied a position of power in her home. But being a woman, she is resigned to the traditional subordinate position of a wife, to her husband Harjot Singh, evidenced in his impulsive decisions of decimating Gurpreet's hard earned material assets. As a mother she decrees her daughters- fourteen year old Kanwar Kaur and four year old Sharanjeet Kaur to be part of the daily toil to complete her incessant travail of domestic labour.

"Do I have to do everything in this house?" Gurpreet shouted from

the kitchen, where she was already cooking the morning meal though it

was barely past dawn. "Look at this princess! Servants she has! Maids

and chaprasis! Sharanjeet. Wake up this minute, or you will get a bucket

of water on your face." (5).

These instances from the novel testify that Gurpreet "inhabits different levels of privilege and discrimination" on account of her positionality.

Deeply entrenched socio-cultural practices and demeaning attitude towards women in patriarchal societies ensure that Gurpreet Kaur as a mother hands down the travesties of her life swamped by stereotypical roles to the generation which succeeds her- her daughters. As Letty Cottin Pogrebin puts it "lifestyles and sex roles are passed from parents to children as inexorably as blue eyes". Accordingly Kanwar and Sharanjeet Kaur are predestined to take to laborious routine domestic grind. Sharanjeet must wake up to her mother's call at five o' clock every morning often thinking "Would she ever have the chance to sleep until the sun climbed into the sky?"(5).

But there was no help. Wake up, Wake up. This was her fate, written on her forehead by the gods, she thought unhappily,... - it was her wretched

fate to have to wake up and dip her hands in piles of excrement. Every morning since she was four years old, she had to start the day by picking up the hot stinking shit that the family's two cows dropped in the courtyard. Then she had to make balls of the disgusting mess and pat them into circular cakes 
against the walls of their house. And the smell- how the smell corrupted her

waking hours and infected her dreams and ruined even her meals. This was what

Sharan resented most of all, for she loved eating. Her joy at the sight of food

turned even the simplest combination of rice and dal into a feast, but when she

raised a morsel of food to her mouth she could only smell the overpowering

odour that had written itself into her skin, instead of the fragrances of turmeric,

fresh rice, butter melting on hot phulkas, green chillies frying (6).

Regarding the roles that a girl child is socially and culturally assigned to perform, Vrinda Nabar opines that "she has to learn quite early on that she is a second-class citizen even in her mother's home...It is she who is roped in to share the domestic chores,..."(57).Hence the childhood of millions of girls like Sharanjeet gets thwarted within the female intersectional matrix, which can be understood through Leslie McCall's "anticategorical" approach to intersectionality. It states that "inequalities are rooted in relationships that are defined by race, class, sexuality and gender" (1778). Accordingly Sharanjeet's position defined by her gender and class, as a young girl from a poor household, places her in an unequal relationship with her only friend Jeeti who belongs to a family with higher economic status. Sharanjeet's class defined by poverty denies her a piece of soap to rid her hands of the repulsive odour of cowdung.

She worked steadily until the wall was covered with even dung pats like so

many rough quarter plates. Then she put the basket away in a corner and

washed her hands hard, wishing she had something other than wood ash

with which to scrub. She longed to run down the road to Jeeti's house and

beg for a small smear of that most coveted of belongings- a bar of scented

soap. Surely Jeeti would not begrudge her a tiny bubble or two? (9).

The poignancy of her situation is reinforced when she is unable to buy a piece of soap to rid her hands of obnoxious odour.

Abandoned by her husband Gurpreet must fulfill her maternal obligation of marrying her daughters. Kanwar aged twenty-four "plain as mud" (20), gets constantly rejected by prospective grooms who prefer sixteen year old Sharanjeet "the one with skin like a sheet of moonlight, the one with eyes like the night sky,that's the one I will marry" (20). Stereotypical codes of feminine beauty for girls of marriageable age comprising fair skin with attractive physical attributes, works against Kanwar and in favour of Sharanjeet's prospects of marriage. Kanwar and Sharanjeet who invariably are the second sex are devoid of choices, in selecting their life partners and must settle for something abysmally lesser than they actually deserved. Kanwar is married to "a widower... with a young son and a few acres of land in a nearby village" (31). Sharanjeet marries Kushwant Singh who lives in Canada but is "blind in one eye"(25). Further both Kanwar and Sharanjeet also occupy "levels of privilege and discrimination". While Sharanjeet gets a chance to educate herself migrates to Canada and enjoys affluence as an entrepreneur, Kanwar's life is a replication of her mother's domestic servitude. Commenting on gender stereotypes Sheryl Sandberg points out that "the gender stereotype introduced in childhood are reinforced throughout our lives and become self-fulfilling prophesies". Conforming to her biological role, Kanwar gives birth to a son and later a daughter Nimmo- Nirmaljeet Kaur. When she is pregnant with her third child she becomes a victim of Partition violence. While she is able to save her daughter from the marauding men, by hiding her in a bin of grain, she is unable to save herself, from the sexual assault by her tormentors and hangs herself.

Girls are socialised to uphold their family's honour. As custodians of its reputation, they must be impeccable, saving themselves from blame or shame.This very instance of suicide is a testimony that in circumstances of a sexual assault, one must strive to keep one's honour inviolable.

Orphaned by the Partition violence, Nirmaljeet Kaur journeys to India alongwith other refugees. Adopted by a Sikh family, Nirmaljeet is educated and married to Satpal Singh. She settles for a life of domesticity, like her mother, in her marital home in Delhi, mothering three children- two sons and a daughter, Kamal. But the religion which she had inherited from her parents, devastates her life in the 
anti- Sikh riots, that inflames the national capital after Prime Minister Indira Gandhi's assassination. Nirmaljeet, assailed by memories of her childhood, of a similar attack braces to save herself and her daughter. "Unlike her mother, she was prepared"(357), as she arms herself with an iron rod and hides her daughter in a steel cupboard, locks it and places the key into a "bowl full of other keys" (357). When the rioters arrive looking for men in the house, she puts up a valiant front, attacks and injures one of the intruders, but is soon overpowered, only to find her house set ablaze. A distraught Nimmo rushes into her house to unlock the cupboard and save her daughter, only to find that the attackers had taken away the bowl of keys.

"Inside the steel cupboard, the safest place- she is there, my little daughter", wailed

Nimmo. Nobody can touch her there" (362).

"It was the last safe place in the world, that bin of grain, stay there my daughter, stay

there, you will be safe. Don't make a noise or they will get you'.(361).

Bedeviled by religion, class and gender Nimmo's efforts to save her daughter's life proves futile. Her mother Kanwar had lost her life, but had managed to save Nimmo's life, by hiding her in a bin of grain.

Cultural conceptions constrain women to conform to stereotypes. Crenshaw posits that "representational intersectionality", connotes "the cultural construction of women of colour" (1245). Likewise, the images of ideal womanhood in the Indian cuturalscape, circumscribes women to a life of domesticity. By mapping the lives of women in her narrative, Anita Rau Badami highlights that across generations, tradition, culture and social propriety ensures the perpetuation of "representational intersectionality". The women in the fictional landscape also share the same destiny of losing their spouses. Gurpreet's husband abandons her, her daughter Kanwar loses her husband Pardeep Singh and her sons to Partition violence, Sharanjeet settled in Canada becomes a widow while on a pilgrimage to India during operation Blue Star against Sikh terrorists. Kanwar's daughter Nirmaljeet's life is shattered during the anti-Sikh riots claiming the lives of her husband Satpal Singh, a son and daughter.

Thus through the chronicling of the lives of women of three generations, one can see the trappings of intersectional inheritances within the Indian socio-cultural milieu.

If "race, class and gender have been the traditional triumvirate of intersectional studies" (Jones,1) caste becomes a defining and determining intersectional factor in the Indian context. Caste as an intersectional inheritance is seen in the character of Leela Bhat in the novel. Her tryst with caste begins right from her birth. She is a child begotten from the wedlock between a "casteless German woman" Rosa Schweers and an Indian Brahmin Hari Shastri. Leela Shastri finds herself doubly ostracised in her natal home, because of her non- Indian, inter-faith identity inherited from her mother and her gender as a girl in an orthodox Brahmin family, with its preference for male children. As a result she was "...Leela Shastri, the pale-eyed, thin daughter of Hari Shastri and Rosa Schweers, a half-and-half hovering on the outskirts of their family's circle of love" (74).Her grandmother Akka refuses to acknowledge Rosa as her daughter-in-law and Leela as her grandchild.

"Half-breed", Akka would mutter out loud. "Worse than an untouchable. At least a

toilet cleaner has caste. But this girl, where does she belong? Tell me, somebody,

where?" (82).

Commenting on caste in her book Caste as Woman, Vrinda Nabar avers that "the girl-child's caste, stamped while she is still unborn, brands her for life" (95). Nabar also speaks of the obsession for a male child in Indian families. This socially pervasive attitude is reflected in Akka's preferential affection for her grandsons (Leela's cousins) and her repudiation of her granddaughter in their joint family.

Akka's dark eyes, which were stones whenever they looked on Leela, turned to

melted tar, She beamed at her grandsons and crooned as if she had not seen them

for a year, "Aha Naani my pet, aha Vishnu my monkey,come,come and sit next to

me!" (76). 
Akka would tell her grandchildren stories from the epics and Panchatantra and on one such occasion, narrates the story of king Trishanku, who in his zeal to go "to heaven in his mortal form", finds himself suspended "in the void between heaven and earth" (77), without belonging either to earth or to heaven. Leela's cousins Narayana and Vishnu immediately relate Trishanku's existence in a limbo to her location within the family. Leela's mother who is unable to come to terms with her own rejection, poised at the crossroads of different cultures, rejects Leela as an infant. Leela's father distanced himself from his wife and "abandoned his daughter to the servants" (81). It is evident that Leela's "half-and-half" status places her in a queer situation, where contrary to caste functioning as the common denominator for social oppression and ostracism, Leela's castelessness becomes the principal cause for her decimation and rejection as an individual by her family. It is Venki, the family's cook who nurtures Leela , encourages her to see her cross-cultural identity as an avenue for opportunity to access the best of both the worlds.

So what is wrong with being like Trishanku? Was he not a lucky fellow

to have a foot in two worlds? Did he not have a heaven of his own around

him? Hanh? Tell me? My chick pea, listen, it can be an advantage to live

neither here nor there, like a frog, comfortable in water and on land. The

thing is to understand how to make use of this ability. $(83,84)$.

After losing her mother, the eight year old Leela works her way to her father's affections, completes her schooling and in the course of pursuing her education at the university, meets Dr.Balachandra Bhat who falls in love with her and sends his marriage proposal to her family. Getting married to a well known respectable family of Hindu Brahmins- "the famous Gundoor Bhats", enables Leela Shastri to permanently erase her ignominious identity of being "half-and-half". The Bhat family wholeheartedly accepts her, "never referring to her mother, never remarking on the colour of her eyes, never asking her why she did not return home to visit her own family during festivals" (99). Her husband's decision to shift to Vancouver, enervates Leela, who feels that she would be rendered rootless again, away from the ancestral home of Bhats in Bangalore. Acquiescing to her husband's wish, Leela alongwith her children Arjun and Preethi immigrates to Vancouver and assimilates herself into the social canvas of the Canadian city, carving an identity of her own and leading a life of contentment and prosperity.

But intersectional inheritances like hereditary genes are seldom suppressed and become dominant in the course of one's life. Accordingly, Leela Bhat's effaced "half-and-half" location manifests itself in her death when she dies mid-air between two worlds - the West and the East- during her journey to India on board the Air India flight bombed by terrorists to avenge the massacre of Sikhs in the antiSikh riots.

Thus Anita Rau Badami's Can You Hear the Nightbird Call? acquaints readers as to how intersectional inheritances never redeem those in its thrall, and how they condition a woman into a passive individual, turning Simone De Beauvoir's ardent wish that “...every human life might be pure transparent freedom", into an imperceptible reality.

\section{REFERENCES}

[1] Crenshaw, Kimberle. "Demarginalising the Intersection of Race and Sex: A Black Feminist Critique of Antidiscrimination Doctrine, Feminist Theory and Antiracist Politics". University of Chicago Legal Forum, vol.1989,iss.1,pp.139-167.

[2] Jouwe, Nancy. "Intersectionality: A Travelling Concept". De Omslag, 2015, omslag. nu/lets-talkdiversity/ intersectionality/.

[3] Badami, Anita Rau. Can You Hear the Nightbird Call?. Vintage, 2007.

[4] Pogrebin, Letty Cottin. "Quotes about Inheritance". www.goodreads.com/quotes/tag/inheritance.

[5] Nabar, Vrinda. Caste as Woman. Penguin Books, 1995.

[6] Mc Call, Leslie. "The Complexity of Intersectionality". Signs, vol.30, no.3,2005,pp.771-1800. JSTOR,www.jstor.org/stable/101086/426800.

[7] Sandberg, Sheryl. Lean In: Women, Work, and the Will to Lead. www.goodreads.com/work/ quotes/21865596-lean-in-women-work-and-the-will-.

[8] Jones, Katherine Castiello, Joya Misra, and K. McCurley. "Intersectionality in Sociology". Sciologists for Women in Society. www.SOC women. Org/wp-content/uploads/sws factsheet_intersectionality.pdf. 
Priya Uthaiah .I \& Dr.Devika Rani.L

AUTHORS' BIOGRAPHY

Priya Uthaiah.I, formerly headed the Dept. of English at Government College, Mandya, Karnataka and is presently pursuing her research on intersectionality as a teacher fellow, in the Dept. of Post Graduate Studies and Research in English at the University of Mysore.

Dr.Devika Rani .L, teaches English in the Dept. of Post Graduate Studies and Research in English at the University of Mysore. She has worked extensively on Black feminism and was awarded doctoral degree for her research on Toni Morrison's fictional oeuvre. 